\title{
Paulina KOWALSKA*
}

\section{ZINTEGROWANY PRODUKT TURYSTYCZNY W DZIALANIACH PROMOCYJNYCH GMINY UNIEJÓW I JEGO ROLA W BUDOWANIU MARKI MIEJSCA}

\begin{abstract}
Zarys treści: Artykuł rozpoczyna się od teoretycznego ujęcia koncepcji budowy marki miejsca oraz kreowania zintegrowanego produktu turystycznego. Następnie dokonano kompleksowej charakterystyki (opisu) walorów przyrodniczych, kulturowych, infrastrukturalnych Uniejowa będących podstawą rozwoju turystyki uzdrowiskowej i rekreacji oraz prowadzenia - na bazie tych zasobów - działań promocyjnych i marketingowych. Działania te podejmowane są w Uniejowie zgodnie z wizją i kierunkami rozwoju gminy określonymi w lokalnych dokumentach strategicznych i planistycznych, nastawionymi na budowę marki uzdrowiska termalnego. Skutki przedsięwzięć promocyjnych obrazuje analiza dynamiki zmian ruchu turystycznego $\mathrm{w}$ gminie przedstawiona w dalszej części opracowania. Oceny efektów działań marketingowych dokonano również na podstawie opinii mieszkańców, którą zbadano metodą sondażową, wykorzystując przygotowany do tego celu kwestionariusz ankietowy. Artykuł kończą wnioski, w ramach których oceniono, na ile produkt turystyczny Uniejowa ma charakter markowy i zintegrowany oraz rekomendacje wskazujące na kierunki dalszych działań, które mogą się przyczynić do wykreowania bardziej kompleksowego i zintegrowanego produktu turystycznego.
\end{abstract}

Słowa kluczowe: turystyka, rekreacja, marketing terytorialny, promocja gminy, marka miejsca, zintegrowany produkt turystyczny, Uniejów

\section{WPROWADZENIE}

Artykuł dotyczy zagadnienia kreowania zintegrowanego produktu turystycznego w ramach działań promocyjnych prowadzonych przez gminę Uniejów i ich roli w budowaniu rozpoznawalnej w skali regionu/kraju marki miejsca. Na wstępie przyjęto założenie, że istniejące na terenie gminy walory: przyrodnicze, kulturowe oraz już istniejące zagospodarowanie turystyczne mogą być skuteczniej wykorzystywane pod warunkiem wykreowania na ich bazie kompleksowej oferty - tj. całościowego produktu turystycznego. Takie ujęcie problematyki badawczej zdeterminowało zakres przedmiotowy opracowania, na który złożyły się część

* Paulina Kowalska, lic., absolwentka studiów I stopnia na kierunku Zarządzanie publiczne (Katedra Zarządzania Miastem i Regionem), Wydział Zarządzania, Uniwersytet Łódzki, ul. Jana Matejki 22/26, 90-237 Łódź; studentka studiów II stopnia na kierunku Administracja, Wydział Prawa i Administracji, Uniwersytet Łódzki, ul. Kopcińskiego 8/12, 90-232 Łódź. 
teoretyczna (dotycząca marketingu terytorialnego ${ }^{1}$ i produktów turystycznych) oraz część empiryczna, w ramach której scharakteryzowano podstawowe walory uzdrowiskowe, przyrodnicze, kulturowe i turystyczne analizowanej gminy, stanowiące podstawę prowadzenia działań promocyjnych gminy Uniejów.

Analiza opisowa działań marketingowych samorządu wraz z badaniami sondażowymi społeczności lokalnej przeprowadzonymi metodą ankietową dały podstawę do sformułowania tezy końcowej odnośnie oceny stopnia integracji działań związanych z kreowaniem kompleksowego produktu turystycznego gminy. Analizy wykazały, że w efekcie promowania produktu turystycznego gminy nastąpił wzrost usług turystycznych w latach 2002-2014. Opracowanie kończy zbiór rekomendacji wskazujących na dalsze możliwości rozszerzania oferty turystyczno-wypoczynkowej Uniejowa.

Celem przeprowadzonych badań było przeanalizowanie prowadzonych przez gminę Uniejów działań promocyjnych oraz ich wpływu na budowanie marki miejsca w działalności uzdrowiskowej, turystycznej i rekreacyjnej. Przedmiotem badań była ocena kompleksowości i stopnia integracji świadczonych usług rekreacyjno-wypoczynkowych, turystycznych, gastronomicznych i hotelowych w gminie Uniejów. Podmiotami badań były władze samorządowe i mieszkańcy.

Podstawową metodą badawczą była analiza opisowa danych statystycznych (BDL, GUS) dotyczących gminy Uniejów, a także dokumentów strategicznych takich jak: Plan Rozwoju Lokalnego Gminy Uniejów na lata 2007-2015, Wieloletnia Prognoza Finansowa Gminy Uniejów na lata 2014-2020, Strategia rozwoju Gminy Uniejów na lata 2013-2020. W badaniach opinii mieszkańców zastosowano metodę sondażową doboru respondentów, z wykorzystaniem kwestionariusza ankietowego. Przeprowadzone badania pozwoliły na uzyskanie ich opinii odnośnie do podejmowanych przez samorząd działań i stosowanych form promocji oraz ich wpływu na obecny wizerunek gminy.

\section{KONCEPCJA MARKI MIEJSCA ORAZ ZINTEGROWANEGO PRODUKTU TURYSTYCZNEGO A ROZWÓJ GMIN UZDROWISKOWYCH}

Miasta i regiony dążą dzisiaj do stworzenia rozpoznawalnej marki miejsca. Marka jest to zbiór odczuć, wyobrażeń, wrażeń, które są odbierane podczas kontaktu z danym miejscem oraz znajdującymi się tam obiektami. Jest to również powstający w wyobraźni odbiorcy obraz, wspomnienie oraz doświadczenie związane z produktami danego miejsca. Marka powinna być przede wszystkim

${ }^{1}$ Andrzej Szromnik definiuje marketing terytorialny jako dążenie jednostek osadniczych do realizacji zamierzonych celów i osiągania rezultatów w warunkach rosnącej konkurencji. Konieczne jest rozpoznawanie kierunku zmian, ale również racjonalne i efektywne użytkowanie posiadanych zasobów. Marketing dąży do sprawnego zarządzania jednostkami samorządu terytorialnego, A. Szromnik, Marketing terytorialny. Miasto i region na rynku, Oficyna a Wolters Kluwer business, Warszawa 2010, s. 16-17, [za:] M. Florek, Podstawy marketingu terytorialnego, AE w Poznaniu, Poznań 2007, s. 18-19. 
atrakcyjna i wyróżniająca się tak, aby w pełni zaspokajała oczekiwania i potrzeby odbiorców ${ }^{2}$.

Skuteczne zarządzanie marką miejsca jest możliwe dzięki gospodarzowi miasta, czyli liderowi, który stanowi dodatkowo wizytówkę miasta i przyciąga dużą grupę odbiorców. Gospodarz marki miejsca podejmuje działania mające na celu utworzenie miejsca odpowiadającego na potrzeby m.in. mieszkańców, turystów czy przedsiębiorców³ ${ }^{3}$.

Koncepcja marketingu miast podkreśla znaczenie miasta jako megaproduktu, tzn. zbioru produktów miejskich materialnych oraz niematerialnych. Megaprodukt odgrywa szczególną rolę w rozwoju miasta oraz wpływa na jego pozytywny wizerunek. Megaprodukt miasta jest dostępny dla wielu jego użytkowników i powoduje otrzymywanie dodatkowych korzyści dzięki konsumpcji produktów miejskich. Do podstawowych elementów megaproduktu należą m.in.: image miasta, system komunikacyjny, klimat kulturowy i klimat przedsiębiorczości, jakość zagospodarowania, samoorganizacja, relacje pomiędzy podmiota$\mathrm{mi}^{4}$; jego elementem składowym może być również produkt turystyczny.

Literatura przedmiotu podaje wiele interpretacji pojęcia produktu turystycznego, co wynika z jego zróżnicowania. A. Panasiuk definiuje produkt turystyczny ,jako cały zestaw dóbr i usług (obok walorów turystycznych) umożliwiających turyście przybycie do miejsca występowania atrakcji turystycznych, pobyt i ich wykorzystanie. [...] Należy również zwrócić uwagę, iż produkt turystyczny w miejscu recepcji obejmuje wszystkie atrakcje, świadczenia i usługi użytkowane bądź odwiedzane w miejscu recepcji”. Natomiast D. Dudkiewicz wyjaśnia, że sednem produktu turystycznego jest zaspokojenie potrzeb i oczekiwań turystów. Decyzja o podjęciu zakupu ma związek z korzyściami, jakie możemy uzyskać, wybierając daną usługę lub dobro ${ }^{6}$.

Produkty turystyczne stanowią źródło wartości i korzyści dla nabywcy. W każdym produkcie wyodrębnia się określoną strukturę, dzięki której możliwe jest dostrzeżenie, na ile konkurencyjny jest dany produkt w porównaniu do innych ofert na rynku turystycznym. Podstawą produktu jest jego rdzeń, czyli pakiet korzyści, jakie można uzyskać, nabywając usługę. Przykładami korzyści, jakie oferuje nam turystyka, są przede wszystkim wypoczynek, rekreacja, zwiedzanie nowych miejsc i kultur, realizowanie swoich zainteresowań, zawieranie znajomości. Kolejnym poziomem produktu turystycznego jest produkt rzeczywisty, czyli zbiór wszystkich usług zawartych w ofercie turystycznej (usługi

${ }^{2}$ J. Pogorzelski, Praktyczny marketing miast i regionów, Oficyna a Wolters Kluwer business, Warszawa 2012, s. 17-19.

${ }^{3}$ Tamże, s. 28-30.

${ }^{4}$ T. Markowski, Marketing terytorialny, Polska Akademia Nauk Komitet Przestrzennego Zagospodarowania Kraju, Warszawa 2006, s. 95-96.

${ }^{5}$ A. Lewandowska, Produkt na rynku ustug turystycznych, [w:] A. Panasiuk (red.), Marketing ustug turystycznych, Wydawnictwo Naukowe PWN, Warszawa 2005, s. 74.

${ }^{6}$ D. Dutkiewicz, Marketing ustug turystycznych wydanie II, ALMAMER Wyższa Szkoła Ekonomiczna, Warszawa 2009, s. 79. 
gastronomiczne, transportowe, rekreacyjne, hotelowe). Produkt poszerzony zaś służy wzbogaceniu produktu i dodaniu do niego nowych, ulepszonych elementów oferty (np. wyposażenie ośrodków hotelowych w basen, siłownię, dostęp do Internetu, komputerów, zagwarantowanie bezpiecznego środka transportu lub możliwości ubezpieczenia). Produkt poszerzony ma za zadanie wyróżniać się wśród innych ofert konkurentów. Ostatnim poziomem produktu turystycznego jest produkt potencjalny. $\mathrm{W}$ ramach tego poziomu firma podejmuje działania przygotowawcze, aby w przyszłości oferowany produkt był kompleksowy i uwzględniał preferencje klientów?

Podział produktu turystycznego ze względu na rodzaj jest bardzo złożony. Elementami produktu są usługi i dobra, które mają wpływać na zaspokojenie potrzeb turystycznych. Może nim być:

- usługa turystyczna,

- rzecz - np. czasopismo turystyczne, mapa, przewodnik,

- impreza turystyczna - np. cykliczna, krajowa, międzynarodowa, pobytowa,

- wydarzenie - może składać się z produktu turystycznego miejsca lub imprezy turystycznej, np. organizowanie festiwali, wydarzeń sportowych,

- obszarowy produkt turystyczny, czyli szlak, region, miejsce, obiekt ${ }^{8}$.

Usługa turystyczna to jeden $\mathrm{z}$ najważniejszych elementów produktu turystycznego i ma ogromne znaczenie w procesie rozwoju turystyki. Usługi zaspokajają potrzeby materialne i niematerialne turystów. Potrzeby materialne, czyli podstawowe, to m.in. korzystanie z usług hotelowych, wyżywienia. Natomiast usługi niematerialne, nazywane komplementarnymi, dają podróżnym możliwość skorzystania na przykład z usług informacyjnych, przewodnickich ${ }^{9}$.

Podstawowymi usługami świadczonymi w zakresie produktu turystycznego są (w nawiasach wskazano obiekty niezbędne do realizacji usług):

- usługi hotelowe, noclegowe (hotele, gospodarstwa agroturystyczne, pensjonaty, ośrodki wczasowe, domy pracy twórczej),

- usługi gastronomiczne (restauracje, bary, puby, kawiarnie, pizzerie, zajazdy),

- usługi transportowe (infrastruktura komunikacyjna: przystanki, dworce, drogi),

- usługi informacyjne (punkty IT, portale internetowe),

- usługi biznesowe, dostarczane zwykle w trakcie podróży i spotkań służbowych, konferencji, sympozjów,

- usługi wypoczynkowe, rekreacyjne, służące uprawianiu aktywności ruchowej, rekreacyjnej (basen, siłownia, gabinety SPA, boiska),

- usługi przewodnickie - np. w czasie imprez wyjazdowych,

${ }^{7}$ M. Johann, Strategie marketingowe w turystyce, Difin SA, Warszawa 2009, s. 52-53.

${ }^{8}$ A. Lewandowska, dz. cyt., s. 79.

${ }^{9}$ E. Świstak, A. Tul-Krzyszczuk (red.), Ustugi w turystyce, Wydawnictwo SGGW, Warszawa 2013, s. 13-17. 
- usługi rozrywkowe i kulturalne, np. koncerty, festiwale,

- usługi rzemieślnicze i handlowe, np. korzystanie z usług kosmetycznych, sprzedaż pamiątek,

- usługi sanatoryjne - wypoczynek połączony z korzystaniem z zabiegów leczniczych ${ }^{10}$.

Wykształcenie produktu turystycznego ma związek z występowaniem determinant zewnętrznych i wewnętrznych. Determinanty zewnętrzne, czyli egzogeniczne, dotyczą otoczenia obszaru. Zaliczamy do nich:

- uwarunkowania ekonomiczne - wpływające na wzrost ruchu turystycznego np. poprzez ceny lub pozyskiwanie środków unijnych do celów turystycznych,

- uwarunkowania technologiczne - pozwalające na efektywniejsze korzystanie z walorów turystycznych i poprawę funkcjonowania obiektów turystycznych (możliwość dostosowania obiektów do potrzeb osób niepełnosprawnych, elektroniczne sposoby płatności),

- uwarunkowania polityczne - wykonywane przez państwo i władze samorządowe,

- uwarunkowania kulturowe, psychologiczne - dotyczące wypoczynku $\mathrm{w}$ danych miejscach oraz ustalenie, jakie formy wypoczynku wybierają turyści i jak je postrzegają ${ }^{11}$.

Natomiast determinanty wewnętrzne produktu turystycznego zależą bezpośrednio od potencjału turystycznego, jaki posiada dane terytorium (np. gmina). Determinanty te wpływają na końcowy kształt przygotowywanego produktu. Są to m.in.:

- walory przyrodnicze,

- walory kulturowe,

- stan infrastruktury turystycznej, komunikacyjnej terytorium i ich dostępność,

- rozwój przedsiębiorczości regionu w zakresie poszukiwania inwestorów,

- kwalifikacje kadry obsługującej turystów,

- działalność instytucji w celu pozyskiwania środków Unii Europejskiej ${ }^{12}$.

Aby wyróżniać się na tle innych konkurentów i sprostać potrzebom klientów, zaczęto podejmować działania w celu wykreowania markowych produktów turystycznych. Struktura markowego produktu turystycznego oprócz podstawowych elementów produktu posiada dodatkową jakość i wartość dodaną oraz zostaje utrwalona $\mathrm{w}$ świadomości turystów. Należy podkreślić, że struktura markowego produktu składa się jeszcze z dwóch zasadniczych elementów:

${ }^{10}$ W.W. Gaworecki, Turystyka, wyd. 4, PWE, Warszawa 2003; B. Mikuta, K. Żelazna, Organizacja ruchu turystycznego na wsi, Wydawnictwo Format-AB, Warszawa 2004, [za:] E. Świstak, A. Tul-Krzyszczuk (red.), s. 16-17.

${ }^{11}$ J. Kaczmarek, A. Stasiak, B. Włodarczyk, Produkt turystyczny, PWE, Warszawa 2005, s. 55-57, [za:] A. Panasiuk (red.), Marketing w turystyce i rekreacji, Wydawnictwo Naukowe PWN, Warszawa 2013, s. 219-220.

12 Tamże, s. 219-220. 
kreatorów marki, którzy ponoszą odpowiedzialność za istnienie turystyki i jej funkcjonowanie w danym obszarze oraz odbiorców (turystów). Markowe produkty turystyczne powinny być odpowiedzią na potrzeby konsumentów. Istotne jest wyznaczenie segmentu, do którego marka jest skierowana. Koncepcja marketingowa zakłada opracowywanie markowego produktu turystycznego dla danego obszaru z uwzględnieniem działań stosowanych w marketingu terytorialnym, co znacząco przyczynia się do ulepszenia poziomu życia mieszkańców i rozwoju turystyki lokalnej ${ }^{13}$.

Dzisiejsi turyści coraz częściej poszukują markowych produktów turystycznych. Dlatego tak ważna jest współpraca podmiotów danego terytorium, by w efekcie wykształcić nie tylko markowy produkt, ale i tworzyć pozytywny wizerunek obszaru. Markowe produkty turystyczne powinny wykazywać następujące cechy:

- niematerialność - związana z motywami podróży lub zakupu towaru,

- komplementarność - potrzeby turysty zaspokajane są dzięki świadczonym usługom różnych przedsiębiorstw, np. usługi noclegowe, gastronomiczne, transportowe,

- podatność produktów na substytucję - występującą w przypadku produktów konkurencyjnych ${ }^{14}$,

- kompleksowość - czyli oferowane dobra i usługi,

- otwartość - tzn. uprzejme przyjmowanie turystów,

- rozpoznawalność - która ma związek z prowadzonymi działaniami marketingowymi, np. oznaczenia typu logo,

- dostępność - czyli oferta produktu adekwatnego do potrzeb turystów ${ }^{15}$.

Zarówno gminy, jak i regiony przygotowują produkty turystyczne odpowiadające popytowi turystycznemu. Warunkiem koniecznym do stworzenia produktu zintegrowanego jest realizowanie zinstytucjonalizowanych czynności. Efektem działań współpracy samorządu terytorialnego z podmiotami gospodarki turystycznej oraz organizacjami turystycznymi jest wytworzenie zintegrowanego produktu turystycznego (oferty turystycznej).

Strukturę zintegrowanego produktu turystycznego przedstawia rycina 1.

Zintegrowany produkt turystyczny powinien posiadać elementy świadczące o istnieniu obszarowego produktu turystycznego, ale i uwzględniać formy aktywności i współpracy podmiotów samorządowych, organizacji i przedsiębiorców ${ }^{16}$.

${ }^{13}$ A. Nitkiewicz-Jankowska, Markowy produkt turystyczny, [w:] A. Panasiuk (red.), Marketing $w$ turystyce i rekreacji, s. 244-263.

${ }^{14}$ A.E. Szczepanowski, Marka produktu turystycznego jako źródło przewagi konkurencyjnej regionu, [w:] Marketing w rozwoju turystyki, Rozdział 2: Markowe produkty turystyczne, Praca zbiorowa, red. J. Chotkowski, Wydawnictwo Uczelniane Politechniki Koszalińskiej, Koszalin 2009, s. 82-83.

${ }^{15}$ Marketing w rozwoju turystyki, s. 84.

${ }^{16}$ A. Panasiuk (red.), Gospodarka turystyczna, s. 43-44. 


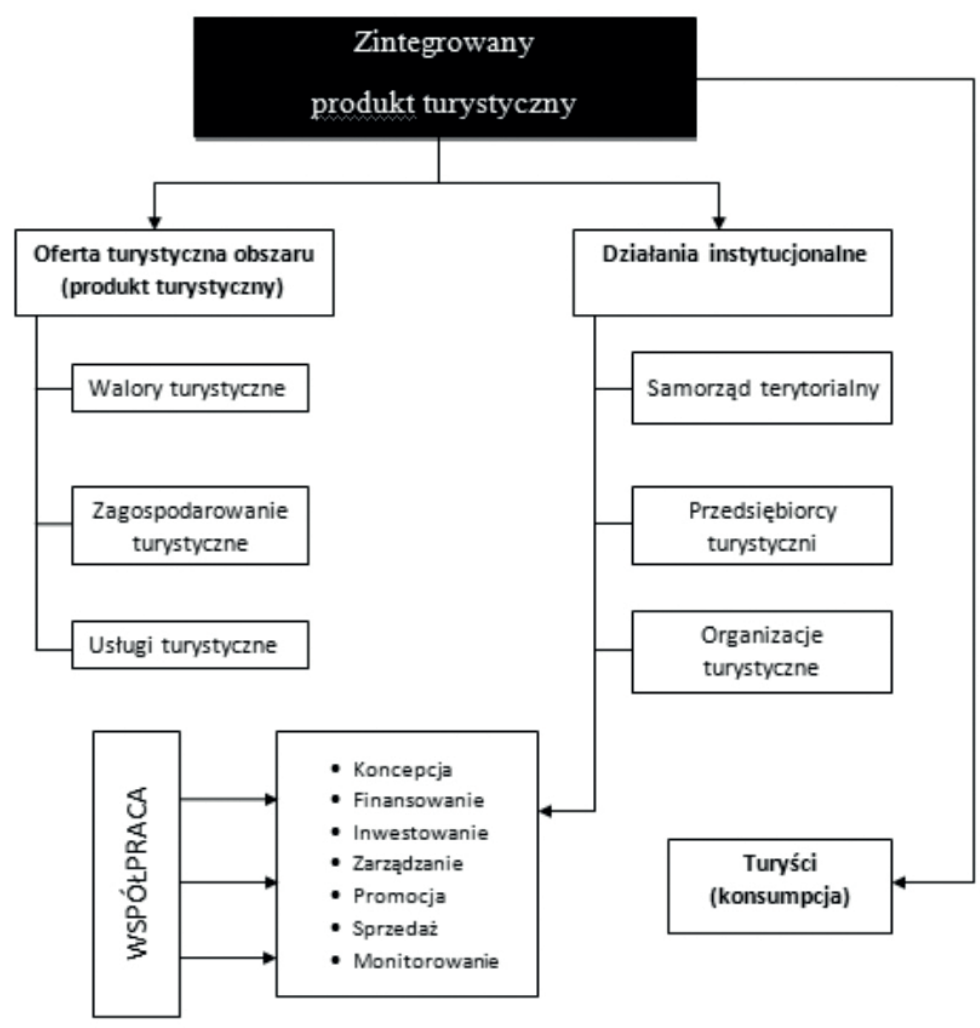

Ryc. 1. Struktura zintegrowanego produktu turystycznego

Źródło: A. Panasiuk, Gospodarka turystyczna, Wydawnictwo Naukowe PWN, Warszawa 2008, s. 44

Mając na uwadze tak zdefiniowany produkt turystyczny, w następnej części artykułu dokonana zostanie analiza zasobów składających się na produkt turystyczny gminy Uniejów. Celem analizy będzie określenie, na ile lokalne zasoby wykorzystywane do rozwoju funkcji i usług turystycznych tworzą zintegrowany produkt.

\section{ANALIZA SKŁADOWYCH PRODUKTU TURYSTYCZNEGO UNIEJOWA}

Analiza zasobów lokalnych będących podstawą rozwoju funkcji turystycznych w Uniejowie zostanie dokonana w celu całościowej oceny stopnia wykształcenia produktu turystycznego Uniejowa i przeprowadzona w podziale na następujące kategorie zasobów: przyrodnicze, kulturowe historyczne, infrastrukturalne i kulturowe niematerialne. Zestawienie zasobów lokalnych Uniejowa i ich wykorzystania jako walorów turystycznych przedstawiono w tabeli 1 . 
Tabela 1. Zasoby lokalne Uniejowa i ich walory składające się na produkt turystyczny

\begin{tabular}{|c|c|c|c|}
\hline $\begin{array}{l}\text { Rodzaje } \\
\text { walorów }\end{array}$ & $\begin{array}{l}\text { Nazwa i charakterystyka } \\
\text { poszczególnych zasobów } \\
\text { lokalnych składających się } \\
\text { na walory turystyczne }\end{array}$ & Funkcje zasobów & $\begin{array}{l}\text { Uwagi } \\
\text { i komentarze }\end{array}$ \\
\hline 1 & 2 & 3 & 4 \\
\hline \multirow{3}{*}{$\begin{array}{l}\text { Przyrodnicze } \\
\text { (naturalne) }\end{array}$} & $\begin{array}{l}\text { Park zamkowy (różnorodne } \\
\text { skupisko drzewostanu, cenne } \\
\text { gatunki drzew i krzewów - około } \\
60 \text { gatunków) }\end{array}$ & $\begin{array}{l}\text { Natura 2000, Uniejowski } \\
\text { Obszar Chronionego Kra- } \\
\text { jobrazu, unikatowe walory } \\
\text { przyrodnicze, turystyka }\end{array}$ & \\
\hline & Kompleks leśny Uroczysko Zieleń & $\begin{array}{l}\text { Natura 2000, Uniejowski } \\
\text { Obszar Chronionego Kra- } \\
\text { jobrazu, walory krajobra- } \\
\text { zowe, przyrodnicze }\end{array}$ & \\
\hline & $\begin{array}{l}\text { Dolina Warty (unikalne gatunki } \\
\text { roślin, niskie torfowiska, natural- } \\
\text { ne łąki oraz rzadkie gatunki pta- } \\
\text { ków o randze międzynarodowej) }\end{array}$ & $\begin{array}{l}\text { Obszar Natura } 2000 \\
\text { PLB300002, turystyka, } \\
\text { rekreacja }\end{array}$ & $\begin{array}{l}\text { Słabo wyko- } \\
\text { rzystywana }\end{array}$ \\
\hline \multirow{6}{*}{$\begin{array}{l}\text { Kulturowe } \\
\text { historyczne }\end{array}$} & $\begin{array}{l}\text { Zamek Arcybiskupów Gnieź- } \\
\text { nieńskich (XIV-wieczny zamek } \\
\text { wybudowany z cegły gotyckiej, } \\
\text { wieża zamkowa) }\end{array}$ & $\begin{array}{l}\text { Turystyka, rekreacja, } \\
\text { funkcja hotelowa, gastro- } \\
\text { nomiczna, krajobrazowa, } \\
\text { zabytkowa, organizowa- } \\
\text { ne są konferencje, eventy, } \\
\text { szkolenia, seminaria, inne } \\
\text { spotkania biznesowe, } \\
\text { bankiety i bale }\end{array}$ & $\begin{array}{l}\text { Kompleksowe } \\
\text { wykorzystanie }\end{array}$ \\
\hline & $\begin{array}{l}\text { Kolegiata Wniebowzięcia Naj- } \\
\text { świętszej Maryi Panny (wznie- } \\
\text { siona w stylu gotyckim, wnętrze } \\
\text { kolegiaty jest w stylu barokowym, } \\
\text { sarkofag wraz z relikwiami błogo- } \\
\text { sławionego Bogumiła) }\end{array}$ & $\begin{array}{l}\text { Religijna, zabytkowa, } \\
\text { walory widokowo-krajo- } \\
\text { brazowe }\end{array}$ & \\
\hline & $\begin{array}{l}\text { Dzwonnica neobarokowa } \\
\text { (wys. } 25 \mathrm{~m})\end{array}$ & Funkcja krajobrazowa & \\
\hline & $\begin{array}{l}\text { Klasycystyczny dworek szlache- } \\
\text { cki (XIX wiek, wykonany według } \\
\text { planu prostokąta, Miejsko-Gmin- } \\
\text { ny Ośrodek Kultury oraz Szkoła } \\
\text { Muzyczna I stopnia) }\end{array}$ & $\begin{array}{l}\text { Funkcja zabytkowa, } \\
\text { edukacyjna, }\end{array}$ & \\
\hline & $\begin{array}{l}\text { Kaplica grobowa rodziny Alek- } \\
\text { sandra Tolla (styl neobizantyjski) }\end{array}$ & Funkcja zabytkowa & \\
\hline & $\begin{array}{l}\text { Układ urbanistyczny miasta } \\
\text { zachowany w charakterze śred- } \\
\text { niowiecznym (fontanna zasilana } \\
\text { wodą termalną) }\end{array}$ & $\begin{array}{l}\text { Funkcja zabytkowa, } \\
\text { turystyka, }\end{array}$ & \\
\hline
\end{tabular}




\begin{tabular}{|c|c|c|c|}
\hline 1 & 2 & 3 & 4 \\
\hline \multirow{5}{*}{$\begin{array}{l}\text { Zagospodaro- } \\
\text { wanie tury- } \\
\text { styczne (baza } \\
\text { turystyczna, } \\
\text { rekreacyjna, } \\
\text { noclegowa, ga- } \\
\text { stronomiczna) }\end{array}$} & $\begin{array}{l}\text { Termy Uniejów (strefa saun, } \\
\text { strefa kąpielowa wewnętrzna } \\
\text { oraz zewnętrzna i strefa restau- } \\
\text { racyjna, bogata oferta zabiegów } \\
\text { balneologicznych i odnowy } \\
\text { biologicznej) }\end{array}$ & $\begin{array}{l}\text { Rekreacja, wypoczynek, } \\
\text { uzdrowiskowa }\end{array}$ & $\begin{array}{l}\text { Zasięg regio- } \\
\text { nalny, ponad- } \\
\text { regionalny } \\
\text { rozpoznawal- } \\
\text { ny w Polsce }\end{array}$ \\
\hline & $\begin{array}{l}\text { Hotele: 1) hotel Uniejów } \\
\text { ecoActive\&Spa; 2) Medical } \\
\text { Spa Hotel Lawendowe Termy; } \\
\text { 3) Hotel Zamek Arcybiskupów } \\
\text { Gnieźnieńskich; 4) Uzdrowisko } \\
\text { Uniejów Park }\end{array}$ & $\begin{array}{l}\text { Noclegowa, kongresowa, } \\
\text { gastronomiczna, wypo- } \\
\text { czynkowa }\end{array}$ & \\
\hline & $\begin{array}{l}\text { Inne obiekty noclegowe, w tym } \\
\text { pensjonaty, gospodarstwa agro- } \\
\text { turystyczne, domki turystyczne, } \\
\text { np. Dom Pracy Twórczej, Zagroda } \\
\text { Młynarska, Kasztel Rycerski } \\
\text { „Na gorących źródłach” }\end{array}$ & $\begin{array}{l}\text { Wypoczynkowa, nocle- } \\
\text { gowa, gastronomiczna }\end{array}$ & \\
\hline & $\begin{array}{l}\text { Obiekty gastronomiczne (np. } \\
\text { Restauracja Herbowa, Restauracja } \\
\text { LaRegina wraz z CoffeeClub, } \\
\text { Karczma w Zagrodzie Mły- } \\
\text { narskiej, Restauracja Termalna } \\
\text { bistro\&cafe, Restauracja Gości- } \\
\text { niec „Nad Wartą”) }\end{array}$ & Gastronomiczna & \\
\hline & $\begin{array}{l}\text { Obiekty rozrywkowe (np. klub } \\
\text { taneczny oraz kręgielnia Nautilus, } \\
\text { lodowisko w sezonie zimowym, } \\
\text { rejs katamaranem po Warcie) }\end{array}$ & Rozrywkowa & \\
\hline $\begin{array}{l}\text { Kulturowe } \\
\text { niematerialne }\end{array}$ & $\begin{array}{l}\text { Wydarzenia kulturalne, rozryw- } \\
\text { kowe, imprezy cykliczne zawarte } \\
\text { w rocznym wykazie Kalendarza } \\
\text { Imprez, ok. } 168 \text { wydarzeń organi- } \\
\text { zowanych w ciągu roku, w tym: } \\
\text { o zasięgu międzynarodowym (2), } \\
\text { europejskim (4), ogólnopol- } \\
\text { skim (19), wojewódzkim (2), } \\
\text { a także regionalnym, powiato- } \\
\text { wym, lokalnym i gminnym }\end{array}$ & $\begin{array}{l}\text { Integracja społeczności } \\
\text { lokalnych, promocja gmi- } \\
\text { ny w wymiarze lokalnym } \\
\text { i regionalnym }\end{array}$ & \\
\hline
\end{tabular}

Źródło: opracowanie własne.

Na bazie posiadanych zasobów gmina Uniejów podejmuje wiele działań mających na celu podniesienie atrakcyjności miasta oraz stworzenie kompleksowej oferty turystycznej. Kluczowym elementem umożliwiającym dotarcie do mieszkańców, ale i turystów jest przede wszystkim promocja nakierowana 
na zbudowanie silnej i rozpoznawalnej marki miejsca. Promocja gminy przyczynia się do rozwoju gminy i stworzenia oferty, która byłaby atrakcyjna dla wielu grup i podmiotów (np. mieszkańców, turystów, inwestorów, organizacji publicznych). Promocja odbywa się za pomocą takich działań, jak wydawanie broszur, ulotek, folderów i plakatów, aż po promowanie gminy na szeroką skalę, tzn. poprzez artykuły w prasie, na stronach internetowych i portalach społecznościowych.

Obecna wizja i misja gminy Uniejów również uwzględniają działania mające na celu rozwój turystyki. Kierunek rozwoju gminy do 2020 roku wyznaczony jest poprzez zdefiniowaną wizję, która brzmi: „Gmina Uniejów w 2020 roku centrum turystyki termalno-uzdrowiskowej i rekreacyjnej w środkowej Polce, wykorzystującej walory przyrodnicze, kulturalne i historyczne"17. Aby zrealizować tę wizję, gmina określiła również swoją misję, która zakłada zaangażowanie wszystkich mieszkańców w budowanie silnej pozycji gminy, która będzie liderem turystyki uzdrowiskowej oraz rekreacyjnej na tle Polski centralnej ${ }^{18}$.

W Planie Rozwoju Lokalnego Gminy Uniejów na lata 2007-2015 jako jedną z najważniejszych inicjatyw/inwestycji wymienia się projekt realizowany w ramach RPO Woj. Łódzkiego „Termy Uniejów” - regionalny markowy produkt turystyki uzdrowiskowej. Zakładał on szereg działań w celu poprawy infrastruktury technicznej, która jest kluczowym czynnikiem wspomagającym rozwój turystki na terenie gminy Uniejów. Jednym z celów projektu było również zwiększenie atrakcyjności gminy oraz wzbogacenie oferty turystycznej. W ramach projektu wpisana w listę zadań została też promocja Uniejowskich Term jako markowego produktu turystyki uzdrowiskowej.

Kolejnymi ważnymi inicjatywami gminy Uniejów były następujące projekty:

- „Budowa i kompleksowa promocja marki Termy Uniejów”,

- „Budowa i kompleksowa promocja marki Eko Uniejów”.

Projekty te służą stworzeniu regionalnej marki Term Uniejów, która bazuje na walorach historycznych, kulturowych oraz przyrodniczych regionu oraz wypromowaniu uzdrowiska jako miejsca umożliwiającego aktywną rekreację ${ }^{19}$.

Prowadzone przez gminę Uniejów działania, realizowane projekty i inwestycje oraz skuteczne pozyskiwanie środków z Unii Europejskiej były w ostatnich latach wielokrotnie nagradzane w licznych rankingach i konkursach regionalnych oraz ogólnopolskich. Wśród najbardziej prestiżowych nagród warto wyróżnić m.in.:

- „Certyfikat Polskiej Organizacji Turystycznej Najlepszy Produkt Turystyczny roku 2012 dla miasta Uniejów za pierwsze w Polsce Uzdrowisko Termalne,

- I miejsce w Rankingu Samorządów Rzeczpospolitej 2013 w kategorii najlepsza gmina w dziedzinie wykorzystania funduszy unijnych,

${ }^{17}$ Strategia rozwoju gminy Uniejów do 2020 roku, s. 106.

${ }^{18}$ Tamże.

${ }^{19}$ Uchwała Nr LV/347/2013 Rady Miejskiej w Uniejowie z dnia 30.12.2013 r. w sprawie uchwalenia Wieloletniej Prognozy Finansowej na lata 2014-2020. 
- Nagroda główna dla gminy Uniejów w VI edycji Ogólnopolskiego konkursu Polska Pięknieje - 7 Cudów Funduszy Europejskich w kategorii turystyka aktywna za projekt Termy Uniejów - regionalny markowy produkt turystyki uzdrowiskowej"20.

Według danych Urzędu Miasta i Gminy Uniejów w latach 2010-2014 na najważniejsze inwestycje $\mathrm{w}$ zakresie promocji przeznaczono ok. 5,6 mln zł. Natomiast wśród przyszłych planów inwestycyjnych związanych z promocją jest wykreowanie produktów regionalnych, czyli: butelkowanie wody termalnej, która posiada właściwości lecznicze wody pitnej oraz wykreowanie produktów powstających z uniejowskich solanek ${ }^{21}$.

Uniejów kształtuje swój wizerunek za pomocą następujących hasel promocyjnych:

- „Uniejów - Miasto Wody, Indian i Rycerzy”, czyli głównych walorów identyfikujących miasto,

- „Termy Uniejów - tu narodzisz się na nowo”, hasło ukazuje potencjał uzdrowiska, które wykorzystuje właściwości leczniczych wód termalnych.

Elementem działań promocyjnych jest również współpraca Urzędu Miasta Uniejów z Uniwersytetem Lódzkim, czego przykładem jest wydawany już od 2012 roku „Biuletyn Uniejowski”. Uniejów poprzez tego rodzaju publikacje stara się budować markę miasta nowoczesnego i promującego walory gminy ${ }^{22}$. Dodatkowo na liście czasopism wydawanych przez Urząd Miasta Uniejów znajdują się jest kwartalnik „Uniejowskie Strony” oraz pismo Towarzystwa Przyjaciół Uniejowa „W Uniejowie”23. Na temat Uniejowa ukazuje się też wiele artykułów w prasie (np. „Echo Turku”, „Polski Dziennik Łódzki”).

Urząd Miasta Uniejów uruchomił ponadto nowoczesne rozwiązanie dla mieszkańców - Samorządowy Informator SMS. System ten pozwala na otrzymywanie ważnych komunikatów i informacji przesyłanych w szybki sposób za pomocą esemesów ${ }^{24}$. Aby zachęcić do odwiedzenia Uniejowa i skorzystania z atrakcji turystycznych, została uruchomiona aplikacja mobilna Uniejów Turystyczny. Przewodnik mobilny poszerza zasięg i sposoby promocji walorów i atrakcji gminy Uniejów oraz Uzdrowiska Termalnego ${ }^{25}$.

Uniejów podejmuje aktywną współpracę $\mathrm{z}$ instytucjami, organizacjami oraz stowarzyszeniami (m.in. z Centralnym Łukiem Turystycznym, uczelniami wyższymi, w tym Akademią Sztuk Pięknych w Lodzi, Politechniką Lódzką i Uniwersytetem Łódzkim), a także z miastami partnerskimi zarówno z Polski, jak i zagranicy (np. Gmina Miasto Turek, Miasto Szczyrk, Węgry, Łotwa, Finlandia) ${ }^{26}$.

${ }^{20}$ Działania Samorzadu Miasta i Gminy Uniejów w kadencji 2010-2014, broszura informacyjna, Urząd Miasta w Uniejowie, s. 20.

${ }^{21}$ Tamże, s. 30.

${ }^{22} \mathrm{http}$ ://biuletynuniejowski.geo.uni.lodz.pl/ (dostęp: 20.04.2015).

${ }^{23} \mathrm{http}: / /$ uniejow.pl/index.php?id=38 (dostęp: 28.04 .2015$)$.

${ }^{24} \mathrm{http} / / /$ uniejow.pl/index.php?id=107 (dostęp: 28.04.2015).

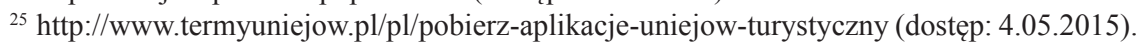

${ }^{26}$ Urząd Miasta Uniejów, broszura informacyjna, 2015. 


\section{ANALIZA DYNAMIKI ROZWOJU TURYSTYKI NA TERENIE UNIEJOWA W LATACH 2002-2014}

Uzyskanie przez Uniejów statusu miejscowości uzdrowiskowej przyczyniło się do rozwoju turystyki na jego terenie. Uniejów najczęściej jest odwiedzany przez mieszkańców większych miast (np. Poznań, Łódź, Bydgoszcz). Do gminy Uniejów dodatkowo przyjeżdżają także turyści zagraniczni (np. z Niemiec, Holandii, Anglii oraz Rosji). Według danych Urzędu Miasta Uniejów średnia długość pobytu osób przyjeżdżających wynosi od 1 do $3 \mathrm{dni}^{27}$.

Dynamikę rozwoju turystyki można potwierdzić na podstawie danych Głównego Urzędu Statystycznego (BDL) dotyczących wybranych turystycznych obiektów noclegowych. Należy podkreślić, że na przestrzeni ostatnich lat (2002-2014) w Uniejowie rośnie liczba miejsc noclegowych. Wyraźny wzrost nastąpił po 2008 roku (z 46 na 117). Natomiast w 2014 roku liczba miejsc noclegowych wynosiła 395, co przedstawia rycina 2.

W latach 2002-2014 nastąpił również wyraźny wzrost liczby noclegów oferowanych w wybranych turystycznych obiektach noclegowych Uniejowa. Na poniższym wykresie (ryc. 2) zauważyć można, że w latach 2002-2009 liczba udzielanych noclegów klarowała się na dość równym poziomie. Natomiast od roku 2010 następował dynamiczny wzrost. Liczba udzielanych noclegów w 2010 roku wynosiła 13 935, natomiast w 2014 liczba tych miejsc wzrosła do 60 974. Przedstawione dane świadczą o tym, że Uniejów jest odwiedzany przez coraz większą liczbę osób.

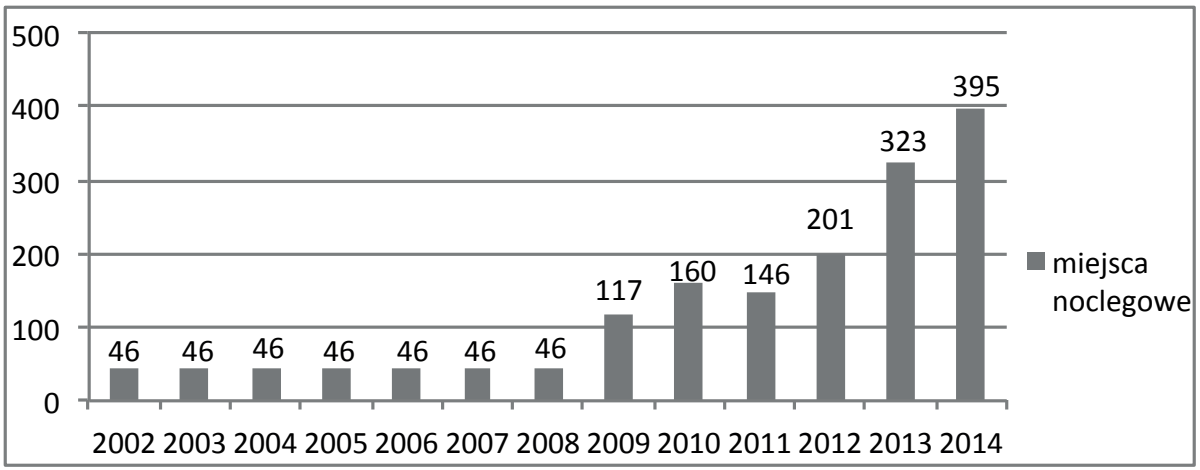

Ryc. 2. Liczba miejsc noclegowych w wybranych turystycznych obiektach noclegowych w Uniejowie w latach 2002-2014

Źródło: opracowanie własne na podstawie BDL

Nastąił bardzo wyraźny wzrost miejsc noclegowych z 46 w roku 2002 do 395 w roku 2014 (wzrost o 349 miejsc noclegowych). Również liczba udzielanych noclegów dynamicznie wzrosła z $4764 \mathrm{w}$ roku 2002 do $60974 \mathrm{w}$ roku 2014 (wzrost o 56210 udzielonych noclegów - ryc. 3).

${ }^{27}$ Plan Rozwoju Lokalnego Gminy Uniejów na lata 2007-2015. 


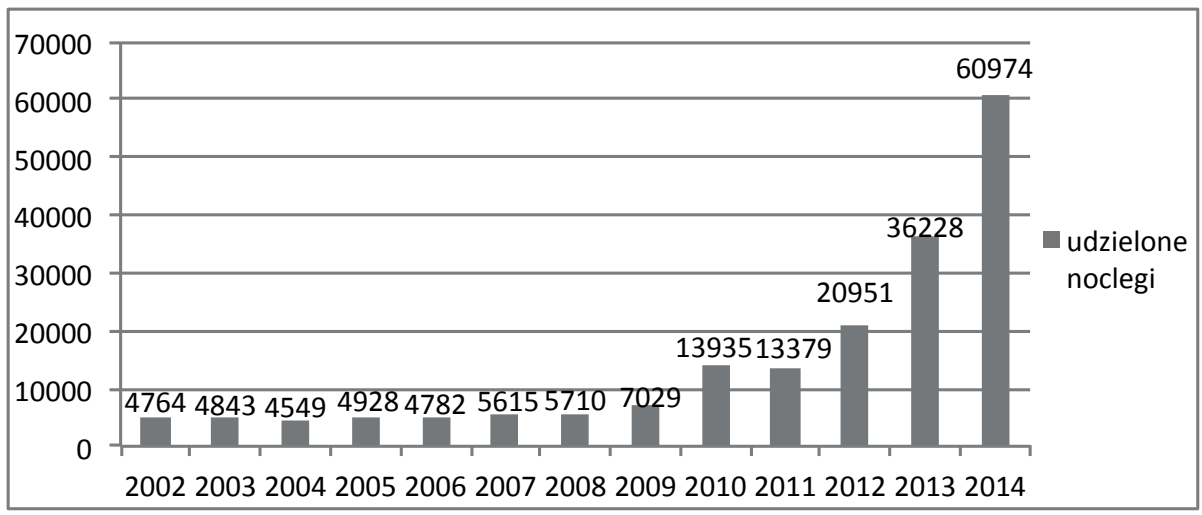

Ryc. 3. Liczba udzielanych noclegów w wybranych turystycznych obiektach noclegowych w Uniejowie w latach 2002-2014

Źródło: opracowanie własne na podstawie danych BDL

\section{OCENA WALORÓW TURYSTYCZNYCH, REKREACYJNYCH, WYPOCZYNKOWYCH I DZIAŁAŃ PROMOCYJNYCH GMINY W ŚWIETLE WYNIKÓW BADAŃ MIESZKAŃCÓW}

Badanie sondażowe mieszkańców zostało przeprowadzone wśród 50 osób (32 kobiety i 18 mężczyzn). Pierwsze pytanie skierowane do ankietowanych dotyczyło obecnego wizerunku Uniejowa. Zdecydowana większość oceniła wizerunek dobrze (26 osób) oraz bardzo dobrze (22 osoby). Nikt nie ocenił wizerunku miasta jako zły lub bardzo zły (ryc. 4).

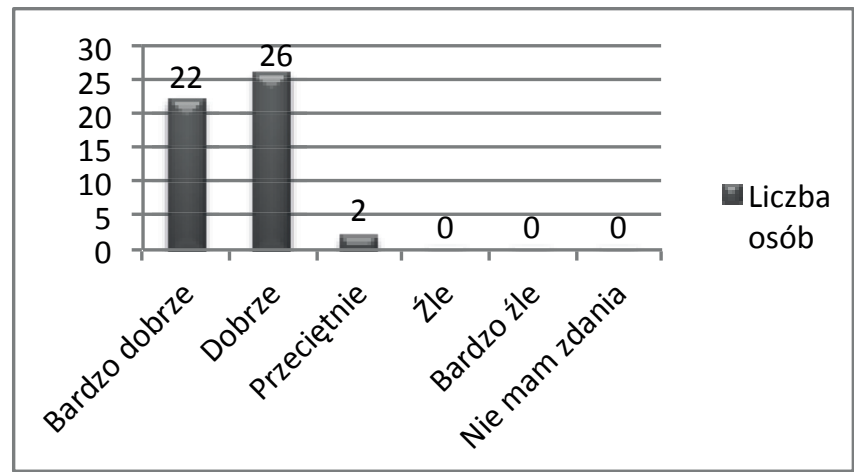

Ryc. 4. Jak ogólnie ocenia Pani/Pan obecny wizerunek Uniejowa?

Źródło: opracowanie własne na podstawie przeprowadzonych badań sondażowych

Kolejne pytanie dotyczyło wskazania (wyboru) maksymalnie 3 głównych celów osób przyjeżdżających do Uniejowa (ryc. 5). Wśród najczęściej udzielanych odpowiedzi był cel zdrowotny (uzdrowiskowy), który został wskazany przez 
$30 \%$ respondentów. Następnie cel rekreacyjno-wypoczynkowy (24\%) oraz kulturowy, czyli zwiedzanie miasta, poznawanie jego historii i tradycji (21\%). Tylko $15 \%$ ankietowanych odpowiedziało, że odwiedzający są tylko przejazdem, natomiast $10 \%$ respondentów wskazało cel biznesowy.

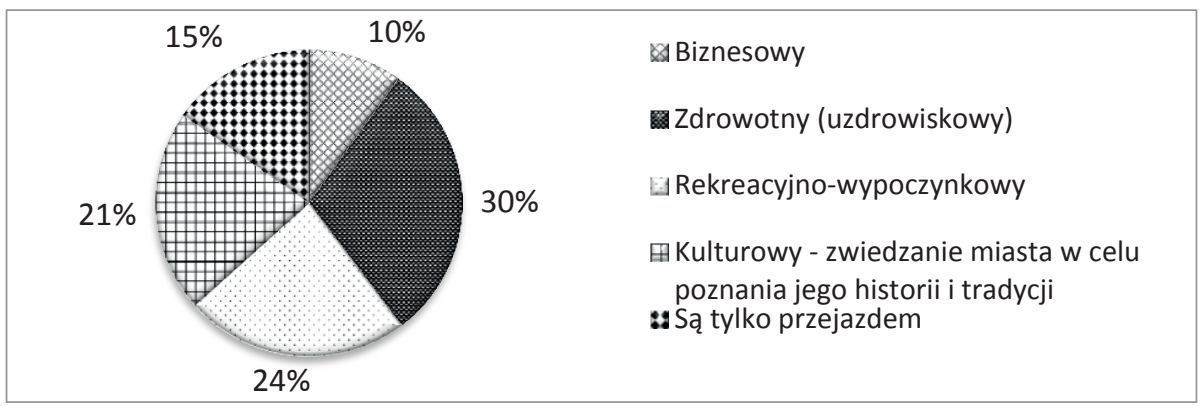

Ryc. 5. Jaki jest, Pani/Pana zdaniem, główny cel osób przyjeżdżających do Uniejowa? Proszę wskazać maksymalnie 3 najważniejsze cele

Źródło: opracowanie własne na podstawie przeprowadzonych badań sondażowych

Pytanie trzecie nawiązywało do określenia stopnia poszczególnych czynników, które wpływają na atrakcyjność miasta (tab. 2). Z przedstawionych danych wynika, że największy wpływ wywiera Uzdrowisko Termalne, najmniejszy zaś rozwój przedsiębiorczości oraz dostępność komunikacyjna.

Tabela 2. Wpływ wybranych czynników na atrakcyjność Miasta Uniejów w opinii mieszkańców

\begin{tabular}{|c|c|c|c|c|c|c|}
\hline \multirow[b]{2}{*}{ Czynniki } & \multicolumn{6}{|c|}{ Liczba wskazanych odpowiedzi } \\
\hline & $\begin{array}{c}\text {,5" } \\
\text { zdecydowanie } \\
\text { tak }\end{array}$ & $\begin{array}{l}\text { „4" } \\
\text { raczej } \\
\text { tak }\end{array}$ & $\begin{array}{c}\text {,3” } \\
\text { umiarko- } \\
\text { wanie }\end{array}$ & $\begin{array}{c}\text { „2" } \\
\text { raczej } \\
\text { nie }\end{array}$ & $\begin{array}{c}\text { "1" } \\
\text { zdecydowanie } \\
\text { nie }\end{array}$ & $\begin{array}{c}\text {,0" } \\
\text { nie mam } \\
\text { zdania }\end{array}$ \\
\hline Uzdrowisko Termalne & 42 & 8 & 0 & 0 & 0 & 0 \\
\hline $\begin{array}{l}\text { Zabytki oraz historia } \\
\text { gminy Uniejów }\end{array}$ & 28 & 15 & 6 & 1 & 0 & 0 \\
\hline $\begin{array}{l}\text { Wydarzenia kulturalno- } \\
\text {-rozrywkowe }\end{array}$ & 20 & 26 & 3 & 1 & 0 & 0 \\
\hline Baza noclegowa & 8 & 20 & 20 & 2 & 0 & 0 \\
\hline Baza gastronomiczna & 2 & 17 & 26 & 4 & 0 & 1 \\
\hline $\begin{array}{l}\text { Obiekty sportowo- } \\
\text {-rekreacyjne }\end{array}$ & 2 & 20 & 23 & 5 & 0 & 0 \\
\hline $\begin{array}{l}\text { Dostępność komuni- } \\
\text { kacyjna }\end{array}$ & 3 & 14 & 22 & 9 & 1 & 1 \\
\hline $\begin{array}{l}\text { Rozwój przedsiębior- } \\
\text { czości - rynek pracy }\end{array}$ & 1 & 7 & 21 & 11 & 2 & 8 \\
\hline Inne, jakie? & 0 & 0 & 0 & 0 & 0 & 0 \\
\hline
\end{tabular}

Źródło: opracowanie własne na podstawie przeprowadzonych badań sondażowych. 
$\mathrm{Na}$ atrakcyjność Uniejowa zdecydowany wpływ mają organizowane wydarzenia kulturalno-rozrywkowe, na które wskazało aż 20 respondentów (ryc. 12). Najwięcej ankietowanych udzieliło odpowiedzi „raczej tak” w kontekście wpływu wydarzeń na atrakcyjność miasta. Tylko jedna osoba spośród badanych wskazała, że wydarzenia kulturalno-rozrywkowe raczej nie wpływają na atrakcyjność miasta.

Najwięcej ankietowanych oceniło bazę noclegową jako czynnik wpływający na atrakcyjność Uniejowa umiarkowanie (20 osób) oraz raczej pozytywnie (20 osób). Tylko 8 respondentów uważa, że baza noclegowa zdecydowanie świadczy o jego atrakcyjności. Natomiast 2 ankietowanych wskazało, że baza noclegowa raczej nie wpływa na atrakcyjność (ryc. 13).

Najwięcej badanych (26 osób) oceniło bazę gastronomiczną jako umiarkowany atut (ryc. 14). Natomiast 17 badanych wskazało, że gastronomia raczej pozytywnie wpływa na atrakcyjność. Tylko 4 ankietowanych udzieliło odpowiedzi, że baza gastronomiczna raczej nie wpływa na atrakcyjność, a 1 spośród ankietowanych nie miał zdania w tej kwestii. Spośród badanych 2 osoby wskazały na zdecydowany wpływ bazy gastronomicznej na atrakcyjność Uniejowa.

Najwięcej osób, bo aż 23 wskazało na umiarkowany wpływ obiektów sportowo-rekreacyjnych na atrakcyjność Uniejowa (ryc. 15). Najmniejszą liczbą wskazań ankietowanych miały odpowiedzi „zdecydowanie tak” (2 osoby) oraz „,raczej nie" (5 osób).

Kolejny czynnik, czyli dostępność komunikacyjna, przez większość ankietowanych został oceniony umiarkowanie (22 osoby). Przy czym 9 badanych wskazało, że dostępność komunikacyjna raczej nie wpływa na atrakcyjność Uniejowa (ryc. 17).

Rozwój przedsiębiorczości został oceniony w badaniu jako umiarkowany czynnik mający wpływ na atrakcyjność Uniejowa (21 ankietowanych). Natomiast 11 respondentów udzieliło odpowiedzi, że rozwój przedsiębiorczości - rynek pracy raczej nie wpływa na atrakcyjność. Należy wskazać, że aż 8 osób nie ma zdania w tej kwestii (ryc. 16). Graficzną ilustrację danych zawartych w tabeli przedstawiono w końcowej części analizy (ryc. 12-17).

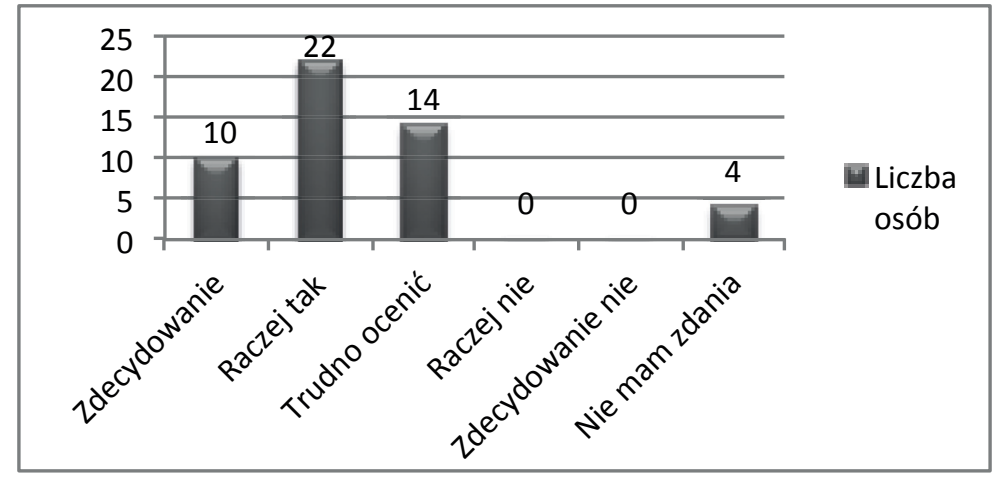

Ryc. 6. Czy podejmowane przez samorząd działania promocyjne są skuteczne i wpływają na rozwój gminy Uniejów?

Źródło: opracowanie własne na podstawie przeprowadzonych badań sondażowych 
W kolejnym pytaniu respondenci ocenili skuteczność działań promocyjnych prowadzonych przez samorząd oraz ich wpływ na rozwój Gminy Uniejów. Największa liczba ankietowanych (22 osoby) udzieliła odpowiedzi „raczej tak”. Natomiast 14 osób wskazało odpowiedź, że trudno ocenić skuteczność działań promocyjnych. Tylko 4 respondentów stwierdziło, że nie ma zdania (ryc. 6).

Kolejne pytanie dotyczyło tego, komu działania promocyjne przynoszą największą korzyść. Najwięcej ankietowanych odpowiedziało, że turyści odnoszą największą korzyść (36\%), a następnie mieszkańcy (26\%). Przy czym 17\% respondentów wskazało, że to władze samorządowe czerpią największą korzyść z prowadzonych działań promocyjnych, natomiast $2 \%$ respondentów zaznaczyło odpowiedź, że nie wie (ryc. 7).

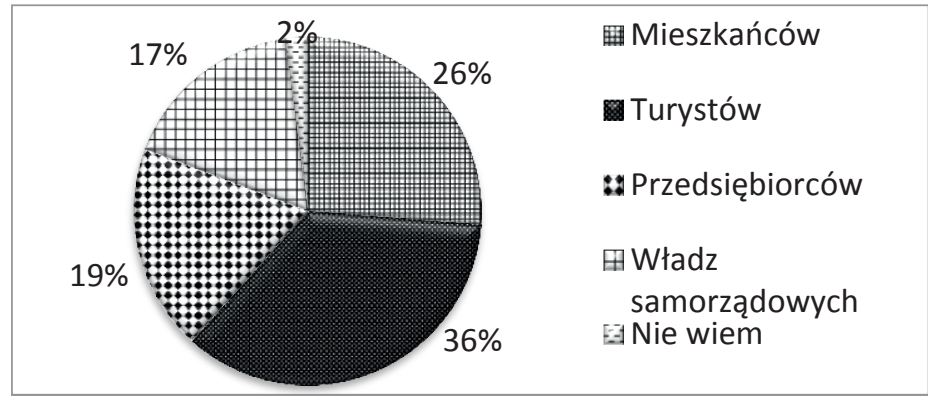

Ryc. 7. Proszę wskazać, komu, Pani/Pana zdaniem, działania promocyjne przynoszą największą korzyść?

Źródło: opracowanie własne na podstawie przeprowadzonych badań sondażowych

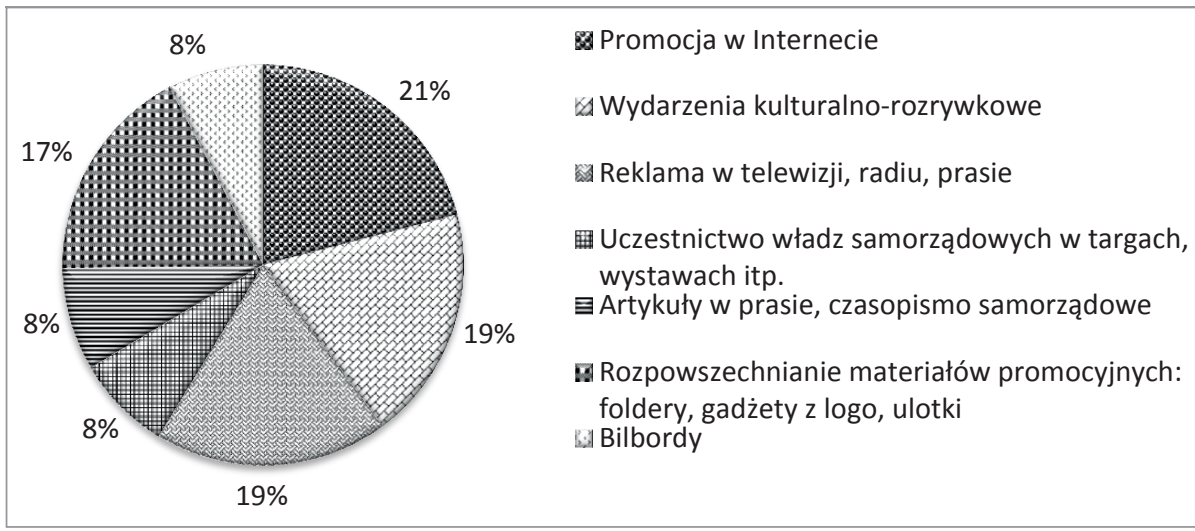

Ryc. 8. Z jakimi sposobami promocji Uniejowa spotyka się Pani/Pan najczęściej? Proszę wskazać 2-3 odpowiedzi

Źródło: opracowanie własne na podstawie przeprowadzonych badań sondażowych

Pytanie piąte dotyczyło sposobów promocji Uniejowa (ryc. 8). Respondenci jako najczęściej rozpoznawane sposoby promocji wskazali: promocję w Internecie (21\% ankietowanych), wydarzenia kulturalno-rozrywkowe (19\% ankietowanych) oraz reklamę w telewizji, radiu, prasie (19\% ankietowanych). Najmniejsza 
liczba ankietowanych (8\%) wskazała na takie działania promocyjne, jak: uczestnictwo władz samorządowych w targach, wystawach itp., artykuły w prasie, czasopismo samorządowe oraz bilbordy.

W pytaniu siódmym zapytano ankietowanych, jaki atut powinien być głównym czynnikiem promocji w Uniejowie (ryc. 9). Najwięcej osób (27) wskazało, że atutem powinny być walory uzdrowiskowe (m.in. woda geotermalna, warunki klimatyczne). Na zabytki Uniejowa jako atut wskazało 13 badanych. Z kolei 7 ankietowanych uważa, że baza turystyczna (tj. noclegowa, gastronomia, informacja turystyczna) powinna być głównym czynnikiem promocji. Najmniej osób wskazało, że czynnikiem promocji powinien być krajobraz, w tym położenie nad rzeką Wartą oraz stan i jakość środowiska przyrodniczego.

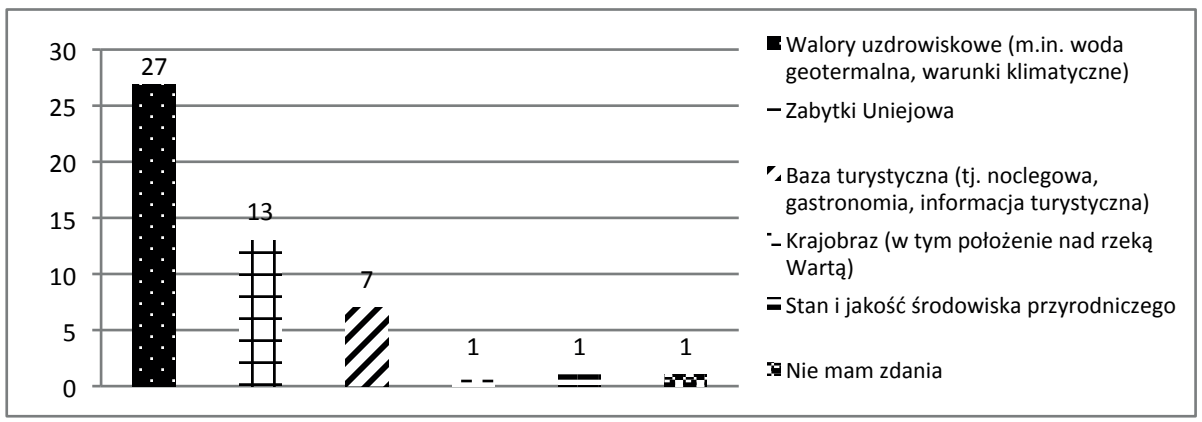

Ryc. 9. Jaki atut powinien być głównym czynnikiem promocji w Gminie Uniejów? Źródło: opracowanie własne na podstawie przeprowadzonych badań sondażowych

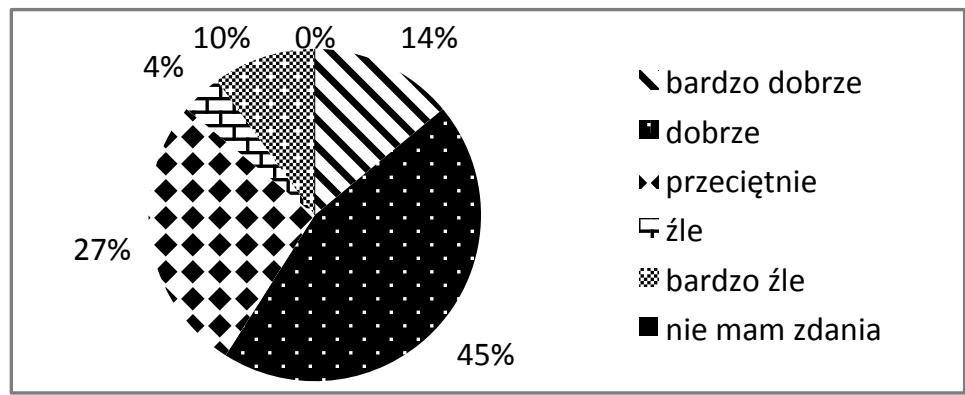

Ryc. 10. Ocena atrakcyjności Uniejowa jako miejscowości o charakterze rekreacyjno-wypoczynkowym

Źródło: opracowanie własne na podstawie przeprowadzonych badań sondażowych

Ostatnie pytanie dotyczyło atrakcyjności Uniejowa jako miejscowości o charakterze rekreacyjno-wypoczynkowym oraz uzdrowiskowym (ryc. 10 i 11). Większość respondentów oceniła Uniejów jako miejscowość o charakterze rekreacyjno-wypoczynkowym dobrze $(45 \%)$ oraz przeciętnie $(27 \%)$. Natomiast najmniej osób oceniło Uniejów źle (4\%). Nikt z ankietowanych nie ocenił Uniejowa bardzo źle. Najwięcej respondentów oceniło Uniejów jako miejscowość 
o charakterze uzdrowiskowym: bardzo dobrze $(42 \%)$ oraz dobrze (32\%). Natomiast $18 \%$ ankietowanych oceniło Uniejów przeciętnie. Nikt z ankietowanych nie ocenił Uniejowa źle i bardzo źle w kontekście miejscowości uzdrowiskowej.

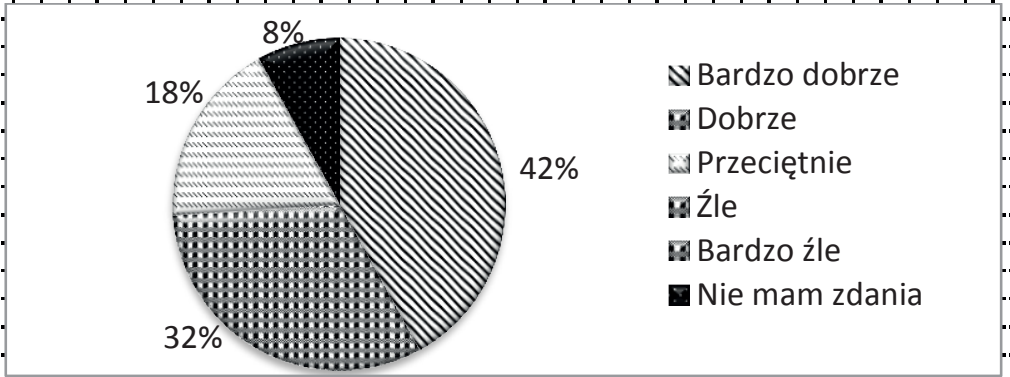

Ryc. 11. Ocena atrakcyjności Uniejowa jako miejscowości o charakterze uzdrowiskowym Źródło: opracowanie własne na podstawie przeprowadzonych badań sondażowych

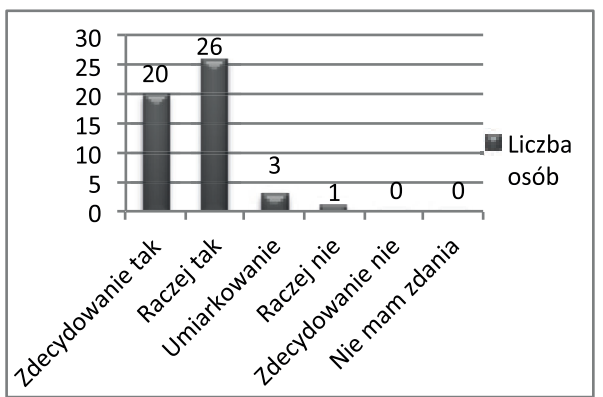

Ryc. 12. Wpływ wydarzeń kulturalno-rozrywkowych na atrakcyjność miasta Uniejów

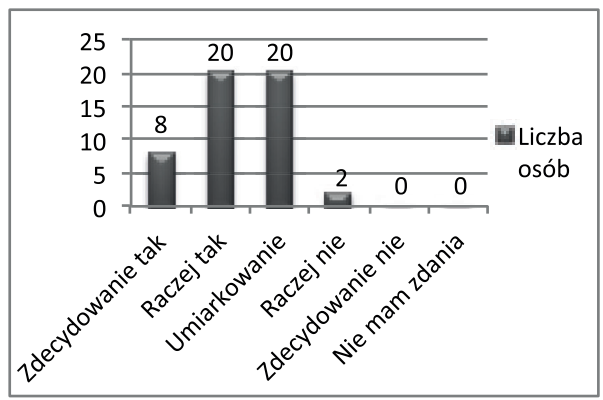

Ryc. 13. Wpływ bazy noclegowej na atrakcyjność miasta Uniejów

Źródło: opracowanie własne na podstawie przeprowadzonych badań sondażowych

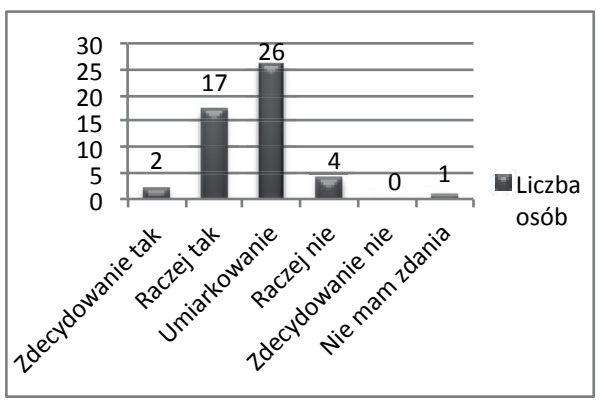

Ryc. 14. Wpływ bazy gastronomicznej na atrakcyjność miasta Uniejów

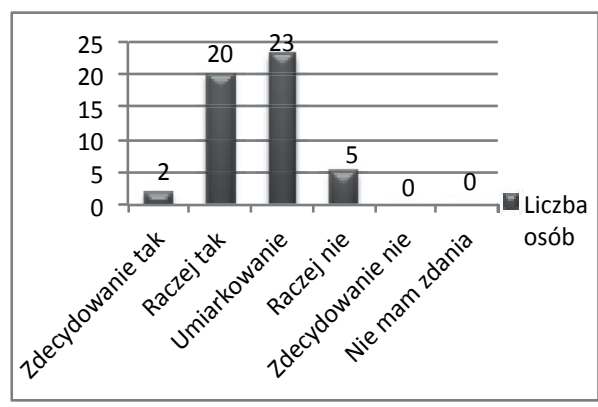

Ryc. 15. Wpływ obiektów sportowo-rekreacyjnych na atrakcyjność miasta Uniejów

Źródło: opracowanie własne na podstawie przeprowadzonych badań sondażowych 


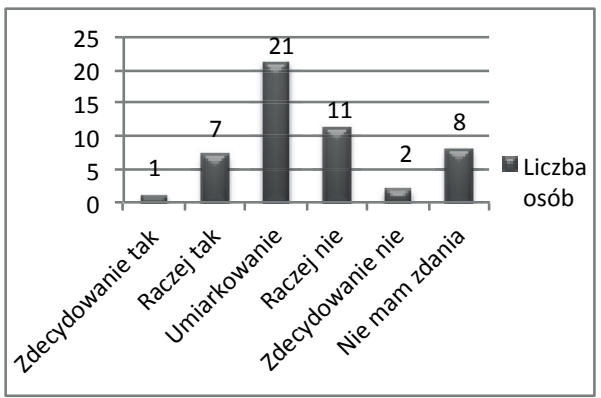

Ryc. 16. Wpływ rozwoju przedsiębiorczości - rynku pracy na atrakcyjność miasta Uniejów

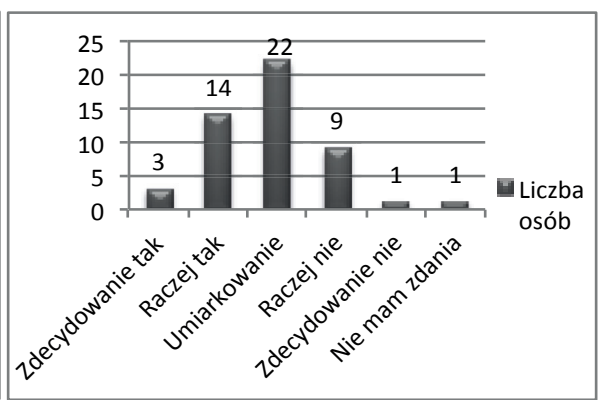

Ryc. 17. Wpływ dostępności komunikacyjnej na atrakcyjność miasta Uniejów

Źródło: opracowanie własne na podstawie przeprowadzonych badań sondażowych

\section{WNIOSKI I REKOMENDACJE}

Przeprowadzone badania sondażowe pozwalają na stwierdzenie, że gmina Uniejów jest przede wszystkim gminą rozpoznawalną. Świadczy o tym uzyskanie w 2012 roku statusu miejscowości uzdrowiskowej. Należy również podkreślić, że Uniejów jest jedyną miejscowością uzdrowiskową w województwie łódzkim. Dzięki wykorzystaniu źródeł geotermalnych i utworzeniu bogatej oferty kompleksu Uzdrowiska Termalnego miasto jest odwiedzane przez coraz większe grono turystów. Dodatkowo Uniejów prowadzi szereg działań marketingowych, $\mathrm{w}$ tym $\mathrm{w}$ formie zaawansowanych projektów promocyjnych, które mają istotne znaczenie w budowaniu pozytywnego wizerunku gminy.

Uniejów, aby wypromować markę miejsca, identyfikuje się za pomocą haseł promocyjnych, które wskazują na główne walory gminy oraz potencjał leczniczych wód termalnych uzdrowiska. Należy stwierdzić, że gmina Uniejów posiada już wypracowaną markę miejsca, którą zdecydowanie jest Uzdrowisko Termalne jako atrakcyjne miejsce rekreacji. To obecność wód geotermalnych spowodowała, że w Uniejowie zaczęły powstawać nowe obiekty i inwestycje wokół Term rozwija się wiele usług komplementarnych z zakresu hotelarstwa, gastronomii, rozrywki i turystyki.

Po przeprowadzeniu analizy walorów gminy Uniejów istotnych dla rozwoju funkcji turystycznej można stwierdzić, że w Uniejowie wykreowano już produkt turystyczny, jednak nie można uznać go jeszcze za produkt w pełni zintegrowany. Pod wpływem prowadzonych działan promocyjnych w Uniejowie dopiero tworzy się kompleks usług turystycznych, rekreacyjnych i wypoczynkowych. Jest to połączenie wielu ważnych usług, $w$ tym m.in.: Term wraz ze znajdującymi się na terenie gminy zabytkami, organizowanymi licznymi wydarzeniami kulturalno-rozrywkowymi oraz rozwijającą się bazą noclegową i gastronomiczną. W celu wykreowania produktu turystycznego kluczowe jest zaangażowanie wielu podmiotów. 
Uniejów jest przede wszystkim gminą rozwijającą się dynamicznie. Wskazuje na to dokonana analiza dynamiki rozwoju turystyki w latach 2002-2014 dotycząca wybranych turystycznych obiektów noclegowych. Gmina jest też jednym z liderów (na tle innych gmin w Polsce), jeżeli chodzi o skuteczne pozyskiwanie środków unijnych. Większość dotychczasowych działań promocyjnych było sfinansowanych $\mathrm{w}$ ramach realizowanych projektów ze środków pomocowych z UE.

W ocenie społecznej (badania sondażowe mieszkańców) wizerunek gminy jest pozytywny; Uniejów postrzegany jest jako miejscowość o charakterze uzdrowiskowym, ale i również rekreacyjno-wypoczynkowym. W celu uzyskania pełniejszego obrazu wizerunku Uniejowa należałoby jednak podobne badania przeprowadzić wśród odwiedzających gminę.

Po dokonaniu powyższych analiz można sformułować następujące szczegółowe rekomendacje ukierunkowane na wykreowanie kompleksowej i zintegrowanej oferty turystycznej, wypoczynkowej oraz rekreacyjnej:

- zagospodarowanie frontów wodnych rzeki Warty do celów rekreacyjnych i wypoczynkowych (promenady nad brzegiem rzeki z usługami drobnej gastronomii),

- uzupełnienie infrastruktury turystycznej (służącej rozwojowi turystyki aktywnej) o: przystań wodną na Warcie dla rozwoju spływów kajakowych we współpracy z innymi gminami (zintegrowany projekt), a także np.: pola golfowe, wypożyczalnię rowerów,

- wzbogacenie oferty dla rodzin z małymi dziećmi, np. nauka jazdy konnej,

- dalsze uzupełnianie oferty noclegowej o obiekty o zróżnicowanym standardzie (np. gospodarstwa agroturystyczne, pensjonaty, domki wczasowe), a także bazy gastronomicznej ze szczególnym uwzględnieniem oferty kuchni tradycyjnej, lokalnej, polskiej,

- koordynacja działalności różnych podmiotów świadczących usługi turystyczne np. w zakresie dostosowania godzin otwarcia obiektów do potrzeb i oczekiwań klientów.

Podsumowując, można sformułować tezę końcową, że obecna oferta turystyczna, rekreacyjna oraz wypoczynkowa nie spelnia jeszcze wszystkich kryteriów zintegrowanego produktu turystycznego.

Uniejów w ostatnich latach podejmuje wiele działań w celu poszerzenia ofert składających się na produkt turystyczny i ich integracji. W gminie oprócz dominującej roli Uzdrowiska Termalnego, walorów naturalnych, zabytków oraz bogatej oferty wydarzeń rozrywkowych i kulturalnych następuje wzrost bazy noclegowej oraz turystycznej. Zintegrowany produkt turystyczny w Uniejowie powinien być na tyle kompleksowy, aby turyści mogli korzystać z oferty turystycznej, rekreacyjnej oraz wypoczynkowej nie tylko przez około 1-3 dni, lecz w dłuższym okresie. 


\section{Bibliografia}

Chotkowski J. (red.), Marketing w rozwoju turystyki, Wydawnictwo Uczelniane Politechniki Koszalińskiej, Koszalin 2009.

Dutkiewicz D., Marketing ustug turystycznych wydanie II, ALMAMER Wyższa Szkoła Ekonomiczna, Warszawa 2009.

Florek M., Podstawy marketingu terytorialnego, AE w Poznaniu, Poznań 2007.

Gaworecki W.W., Turystyka, wyd. 4, PWE, Warszawa 2003.

Johann M., Strategie marketingowe w turystyce, Difin SA, Warszawa 2009.

Kaczmarek J., Stasiak A., Włodarczyk B., Produkt turystyczny, PWE, Warszawa 2005.

Lewandowska A., Rozdziat 5 Produkt na rynku ustug turystycznych, [w:] A. Panasiuk, Marketing ustug turystycznych, Wydawnictwo Naukowe PWN, Warszawa 2005.

Markowski T., Marketing Terytorialny, Polska Akademia Nauk Komitet Przestrzennego Zagospodarowania Kraju, Warszawa 2006.

Mikuta B., Żelazna K., Organizacja ruchu turystycznego na wsi, Wydawnictwo Format-AB, Warszawa 2004.

Nitkiewicz-Jankowska A., Markowy produkt turystyczny, [w:] A. Panasiuk (red.), Marketing w turystyce i rekreacji, Wydawnictwo Naukowe PWN, Warszawa 2013.

Panasiuk A. (red.), Gospodarka turystyczna, Wydawnictwo Naukowe PWN SA, Warszawa 2008.

Panasiuk A. (red.), Marketing $w$ turystyce i rekreacji, Wydawnictwo Naukowe PWN, Warszawa 2013.

Pogorzelski J., Praktyczny marketing miast i regionów, Oficyna a Wolters Kluwer business, Warszawa 2012.

Szczepanowski A.E., Marka produktu turystycznego jako źródło przewagi konkurencyjnej regionu, [w:] Marketing w rozwoju turystyki, Rozdział 2: Markowe produkty turystyczne, Praca zbiorowa, red. J. Chotkowski, Wydawnictwo Uczelniane Politechniki Koszalińskiej, Koszalin 2009.

Szromnik A., Marketing terytorialny Miasto i region na rynku, Oficyna a Wolters Kluwer businness, Warszawa 2010.

Świstak E., Tul-Krzyszczuk A. (red.), Ustugi w Turystyce, Wydawnictwo SGGW, Warszawa 2013.

\section{Strategie oraz plany:}

Plan Rozwoju Lokalnego Gminy Uniejów na lata 2007-2015.

Strategia rozwoju Gminy Uniejów na lata 2013-2020.

Wieloletnia Prognoza Finansowa Gminy Uniejów na lata 2014-2020.

\section{Broszury informacyjne:}

Działania Samorzadu Miasta i Gminy Uniejów w kadencji 2010-2014, Urząd Miasta w Uniejowie. Urząd Miasta Uniejów, broszura informacyjna, 2015.

Strony internetowe:

http://uniejow.pl/index.php?id=38 (dostęp: 28.04.2014).

http://uniejow.pl/index.php?id=107 (dostęp: 28.04.2014).

http://www.termyuniejow.pl/pl/pobierz-aplikacje-uniejow-turystyczny (dostęp: 4.05.2014).

http://biuletynuniejowski.geo.uni.lodz.pl/ (dostęp: 20.04.2014).

[Wpłynęło: maj 2016; akceptacja: czerwiec 2016] 


\title{
INTEGRATED TOURIST PRODUCT IN PROMOTIONAL ACTIVITIES OF UNIEJOW MUNICIPALITY AND ITS ROLE IN PLACE BRANDING
}

\begin{abstract}
Summary
The article starts with the theoretical discussion of the concept of territorial brand building and the creation of an integrated tourist product. This is followed by a comprehensive description of the natural, cultural and infrastructural resources of Uniejow, which are a basis for spa tourism and recreation development, and the promotional and marketing activities carried out on the basis of these resources. These activities are undertaken in Uniejow in accordance with the vision and directions of development of the municipality, which are specified in local strategic documents and strategic plans oriented to brand building of thermal spa. Analysis of changes in tourism in the municipality reveals the effects of promotional projects realized so far. Evaluation of the effects of marketing efforts was also based on the opinions of the citizens, which were examined by means of a questionnaire survey. The article ends with conclusions in which it was rated how far the tourist product of Uniejow is branded and integrated; in the last part of the paper there are recommendations for further actions to help create a more comprehensive and integrated tourist product.
\end{abstract}

Keywords: tourism, recreation, place-based marketing, promotions, place branding, integrated tourist product, Uniejów 